\title{
Enediyne compounds - new promises in anticancer therapy
}

MATIJA GREDIČAK

IVANKA JERIĆ*

Ruđer Bošković Institute

Division of Organic Chemistry

and Biochemistry

10002 Zagreb, Croatia

Accepted January 22, 2007
Scientists of all kinds have long been intrigued by the nature, action and potential of natural toxins that possess exceptional antibacterial and anticancer activities. These compounds, named enediynes, are among the most effective chemotherapeutic agents known. Often compared with intelligent weapons, due to the unique structure and sophisticated mechanism by which they destroy double-helical DNA, enediyne antibiotics are nowadays the most promising leaders in the anticancer therapy. Apart from their diversity, enediyne compounds share some structural and functional similarities. One fragment of a structure is responsible for the recognition and transport, another part acts as molecular trigger while the third, reactive enediyne unit, undergoes Bergman cycloaromatization and causes DNA breakage. Members of the enediyne family are already in clinical use to treat various cancers, but more general use is limited by their complex structure, which makes them formidable targets for synthetic chemists. There are three main approaches in the design of new enediyne-related compounds: improvement of enediyne "warheads", increasing the selectivity and control of chemical or photo-induced activation. This paper gives an overview of naturally occurring enediynes, their mode of action and efforts undertaken to design artificial enediyne-related DNA cleaving agents.

Keywords: enediynes, antitumor agents, Bergman cyclization, DNA-cleaving

Chemotherapy is usually the first choice for the treatment of many cancer types. According to the American Cancer Society, more than 100 drugs are currently used for chemotherapy, alone or in combination with other drugs or treatments. Many more have been developed as anticancer drug candidates, but only a few of them are expected to come into clinical practice. These drugs vary widely in their chemical composition, how they are taken, their usefulness in treating specific forms of cancer, and their side effects.

\footnotetext{
* Correspondence, e-mail: ijeric@irb.hr
} 
The majority of anticancer drugs affect cell division or DNA synthesis and function and can be classified as alkylating agents, antimetabolites, anticancer antibiotics, mitotic inhibitors and plant alkaloids. Some chemotherapeutics do not directly interact with DNA, but rather target molecular abnormality in certain types of cancer. In addition, some drugs are used to modulate cancer cell behavior, without directly attacking, like in the hormone treatment.

Development of new efficient anticancer drugs requires a detailed knowledge of the mechanism of drug action at the cellular and molecular levels. Since most anticancer drugs express their activity through the interaction with DNA, extensive research on DNA-drug complexes was undertaken. In the last decades, efforts in this field resulted in useful information about DNA conformations and DNA-drug interactions. There are several ways of interaction between DNA and a drug and they can be classified as follows (1):

- formation of non-covalent complexes achieved through intercalation, insertion between base pairs (daunorubicin [DNC] and doxorubicin [DOX]) or groove-binding (distamycin A),

- formation of covalent linkage between the DNA and anticancer drug (cisplatin, mitomycin C),

- binding to the DNA through some other mechanism and breakage of the DNA backbone (duocarmycin, bleomycin [BLM]/pepleomycin [PEP], enediyne antibiotics).

Development of high-resolutions X-ray diffraction and nuclear magnetic resonance (NMR) techniques, together with thermodynamic studies and molecular modeling made a great contribution to disclosing the basic principles in DNA-drug interaction (2-4). The most striking finding that came out of it is that targets for drug's action are specific reactive, nucleophilic sites distributed on the surface of the double helix. In the minor groove, $\mathrm{N} 2$ of the guanine base is susceptible to drug action and the place where most of the alkylating agents act. Also, a number of anthracycline DNA-binding drugs form complexes or adducts involving N2 of guanine in the first stage of action (DNR/DOX, Fig. 1). In addition, $\mathrm{N} 3$ atom of guanine and adenine in the minor groove is also favorable for drug action (dystamicin A and duocarmycin, Fig. 1), as well as N7 of guanine, which is the reactive site for alkylating agents and metal ions. Structural interactions of platinum anticancer compounds with DNA have been extensively studied. Cisplatin forms intrastrand cross-link with two N7 of guanine (Fig. 1), which is converted into a more stable interstrand bi-dentated adduct (1). It is assumed that the biological activity of cisplatin is related to the interactions of certain proteins with the cisplatin-DNA adduct. These interactions are responsible for the tumor cell death, through not fully elucidated mechanism(s). Some anticancer drugs do not target DNA bases, but rather cleave the DNA backbone. Bleomycin (BLM) is clinically used in combination chemotherapy for the treatment of various types of cancers (5). In-site activation and reaction of DNA and BLM necessitate two cofactors: $\mathrm{Fe}(\mathrm{II})$ and $\mathrm{O}_{2}$. Activated BLM is not stable $\left(t_{1 / 2}=2 \mathrm{~min}\right.$ at $0{ }^{\circ} \mathrm{C}$ in the presence of DNA), it readily abstracts $\mathrm{C}\left(4^{\prime}\right)$ hydrogen atom from the deoxyribose backbone of the DNA (Fig. 1) (6). Finally, enediyne antibiotics belong to the family of highly potent anticancer agents that bind to specific DNA sequences and cause 


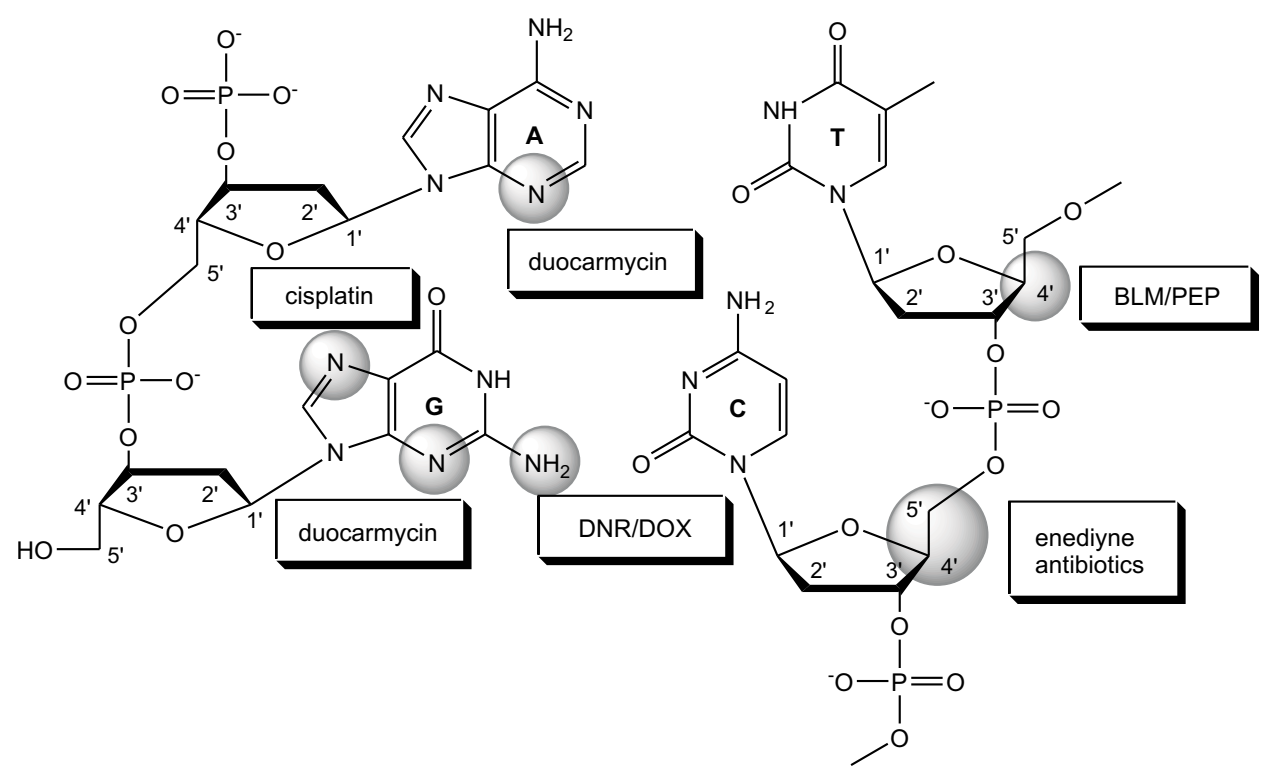

Fig. 1. Schematic presentation of the A-T and G-C base pairs in the minor groove with designated sites of anticancer drug action.

double-stranded DNA lesions. Their positioning within the minor groove is such that the active form of a drug can abstract two hydrogen atoms from the sugars of opposite strands. Fig. 1 schematically represents sites of action of some anticancer drugs.

Peptides are generally considered poor therapeutics due to their high flexibility, low enzymatic stability and polarity, which disable them to pass biological membranes. At the same time, peptides and proteins are of the key importance in many chronic and infectious disorders. Also, a number of peptides with anticancer use or potential have been reported (7). Considerable efforts have been invested in designing compounds with improved bioavailability and capability to mimic peptide functions. Laboratory for carbohydrate, peptide and glycopeptide research at the Ruđer Bošković Institute has a long tradition in the design, synthesis, analysis, conformations, dynamics and structure-activity relationship of biologically relevant peptides, glycopeptides and peptidomimetics (8-16). In recent years, we have been dedicated to carbohydrate-modified amino acids and peptides and found them suitable models for the study of biological phenomena (8, $9,11,13,16)$. During that time, conformational preferences of modified peptides established by NMR spectroscopy and molecular modelling (10), as well as fragmentation pathways evidenced by mass spectrometric analysis (12), have widened our knowledge and added some new "puzzles « necessary to understand complex biological »images «. Lately, we have decided to enrich the peptidomimetic family with new enediyne-related members (15). In this paper, general knowledge of naturally occurring enediynes, their mechanism of action and enediyne-related structures are presented. 


\section{ENEDIYNE ANTICANCER ANTIBIOTICS}

\section{Structure and mechanism of action}

Enediyne antibiotics, a relatively new class of anticancer agents, have been a subject of great interest and intensive research among chemists and biologists since their discovery in the mid-1980s. They possess an exceptional biological profile owing to their unique molecular structure, striking mode of action and high potency $(17,18)$. The first member of this class, neocarzinostatin chromophore, was described in 1985 (19). Two years later, the first members of the calicheamicin (20) and esperamicin (21) family were isolated, followed by the report on dynemicin characterization in 1989 (22). Fig. 2 shows the structures of some naturally occurring enediyne antibiotics. As highlighted, the common structural motif among enediyne antibiotics is an enediyne moiety (Z-hexa-1,5-diyn-3-ene) found captured within a 9- or 10-membered ring.

Apart from their complexity, the structure of enediyne anticancer antibiotics can be simplified by comparison with modern weapons (Fig. 3). Part of a structure, responsible for recognition and transport, delivers the whole, yet inactive "package" to the DNA.

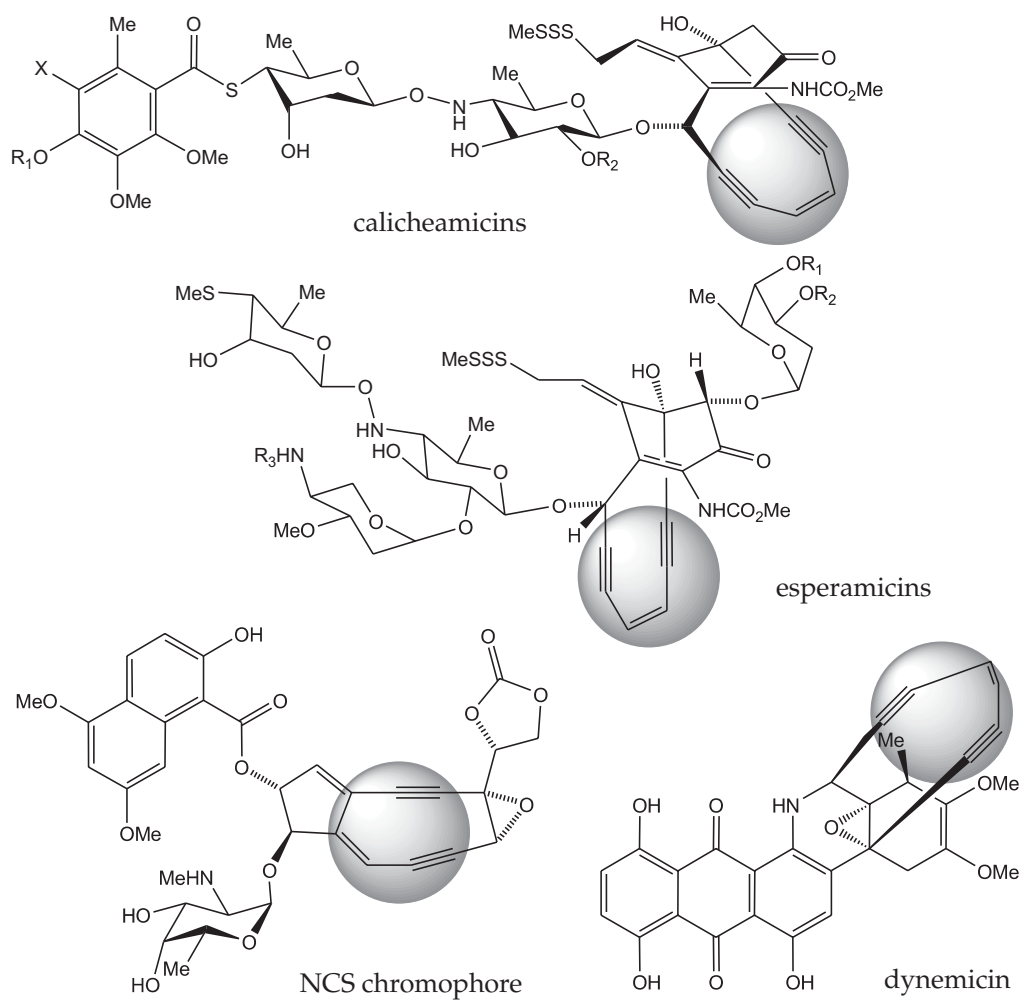

Fig. 2. Naturally occurring enediyne antibiotics. 
After docking into the minor groove, the process can start. On-site activation sets forward a molecular trigger; the cascade of reactions ends with contraction of the enediyne »warhead.«Highly reactive structure formed in this process is capable of the DNA double helix breakage.

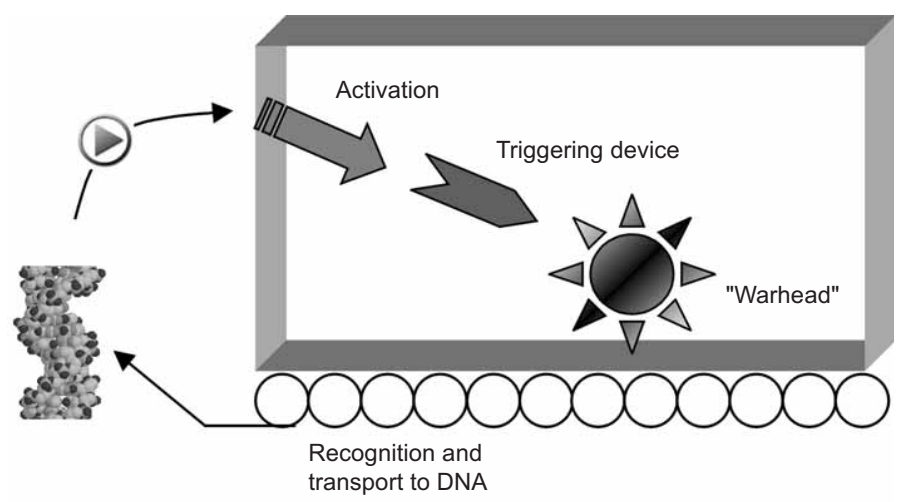

Fig. 3. Schematic presentation of the enediyne antibiotic's mechanism of action.
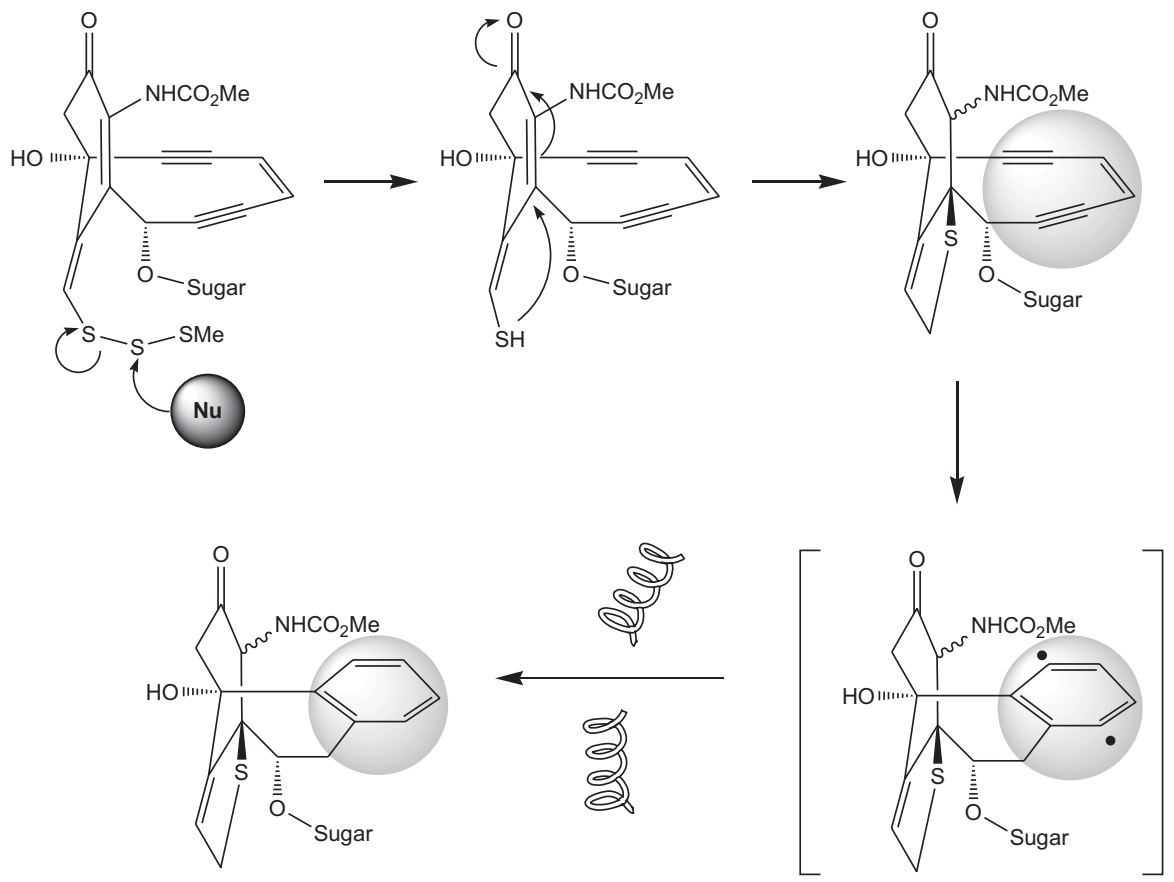

Fig. 4. Mechanism of DNA cleavage by the calicheamicin family of enediyne antibiotics. 
Calicheamicins (Fig. 2) were the first enediyne antibiotics whose mechanism of action was elucidated in more detail. The extended sugar part consists of unusually linked monosaccharide units and the substituted benzene ring serves as a delivery service, which binds the molecule to the minor groove of double-helical DNA. Nucleophilic attack on the allylic trisulfide moiety has the function of triggering device activation (Fig. 4). A thiol formed in the first step initiates a cascade of reactions that cause a significant change in the structural geometry of a molecule. These changes have a special impact on the enediyne moiety captured within the 10-membered ring. As a consequence of changed molecule geometry, a process known as Bergman cycloaromatization takes place (23). Enediyne moiety forms a highly reactive benzene diradical that strips hydrogen atoms from the sugar phosphate backbone of DNA strands, causing scission of the DNA double helix (24).

\section{Bergman cycloaromatization - an insight into the mechanism of activation}

In 1972, the first detailed study of the unique behavior of acyclic Z-enediynes upon thermal activation was described (23). It was realized that a simple enediyne A (Fig. 5), when heated in solution, gave benzene-related products $C$, depending on the solvent used. Bergman (23) recognized the importance of the highly unstable 1,4-didehydro radical $\mathrm{B}$, responsible for the abstraction of two atoms from the accessible donor (e.g. solvent), leading to the stable benzene structure C (Fig. 5).

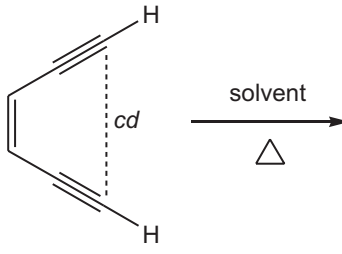

A

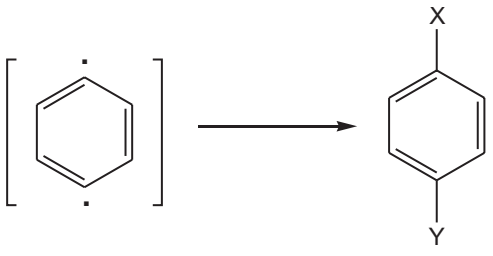

B

\section{C}

Fig. 5. Bergman cycloaromatization of acyclic enediynes.

Bergman cycloaromatization (23) invoked a great deal of interest among physical organic and theoretic chemists, but experienced a real revival with the discovery of enediyne anticancer antibiotics. Cycloaromatization of enediyne functionality, the cause of the DNA cleavage, make enediyne compounds unique in the group of chemotherapeutic agents. Combined experimental and computational methods were used to determine the factors that affect reactivity of $Z$-enediynes in the Bergman reaction and they can be classified as follows (25):

- $c d$ distance; distance between the two terminal acetylenic carbons (Fig. 5),

- difference in strain energy between the enediyne and the transition state,

- concentration of the trapping agents,

- substituent effects. 
Cyclic enediynes generally undergo the Bergman reaction at considerably lower temperatures than the acyclic ones. It was postulated that, in the absence of other factors, the interatomic $c d$ distance is the factor that determines the rate of the Bergman reaction. For example, enediynes with a $c d$ value between 3.20 and $3.30 \AA$ cyclize spontaneously at room temperatures, while those with $c d>3.70 \AA$ do not. Thus, shortening the $c d$ value is a way to overcome the energy gap necessary for the cyclization. It can easily be achieved by complexation with transition metals allowing smooth control of the $c d$ value by means of ionic radii (26). Also, it was found that substituents at the terminal acetylenic carbons have significant influence on the energy of the Bergman cyclization, while those attached to the vinyl carbons generally have no influence.

Contrary to cyclic enediynes, the main factor determining the rate of the Bergman cyclization of acyclic endiynes seems to be the difference in the strain energy between the enediyne and the transition state. Also, the solvent used and the concentration of hydrogen donors are to be taken into account when comparing cyclization rates of different enediyne compounds.

\section{Designed DNA-cleavers - enediyne anticancer antibiotics modifications}

Enediyne anticancer antibiotics are extremely potent DNA cleavers, but highly toxic, so there is an urgent need for new enediyne-related structures with maximum activity towards tumor cells and minimum toxicity towards normal cells. Also, structural complexity of natural enediynes calls for synthetically more accessible analogs. There are two main criteria of efficient artificial DNA cleavers: molecular recognition measured in selectivity and DNA scission scaled in activity (27).

Having in mind the three main structural and functional domains of enediyne compounds, modifications are directed toward:

- design of new enediyne »warheads « with better control over the cycloaromatization mechanism,

- selective recognition and target-directed delivery system,

- triggering device sensitive to chemical or photo-induced activation (28).

Enediyne warheads. - Nicolaou and co-workers (29) synthesized the first generation of designed enediynes (I in Fig. 6) in order to define the simplest model still capable to cleave the DNA molecule. It was shown that the derivative with a 10-membered ring ( $n$ $=2$ ) undergoes the Bergman cyclization at room temperature while those with larger rings $(n=3-8)$ were stable. Contrary to that, Nicolaou and co-workers were not able to synthesize a derivative with a 9-membered ring $(n=1)$. Following these findings, the water-soluble derivative II (Fig. 6) was prepared and it was found that it undergoes Bergman cycloaromatization at $37^{\circ} \mathrm{C}$ and cleaves double-stranded DNA.

Maier and co-workers (30) have prepared the bicyclic derivative III (Fig. 6), which is stable at room temperature, but cyclization occurred at elevated temperature. It was found that metal ions facilitate thermally induced Bergman cyclization of stable enediynes through coordination or complexation. Thus, the molybdenum derivative of enediyne IV (Fig. 6) is far more susceptible to cyclization than the free ligand (31). 


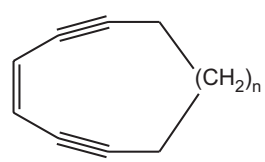

I

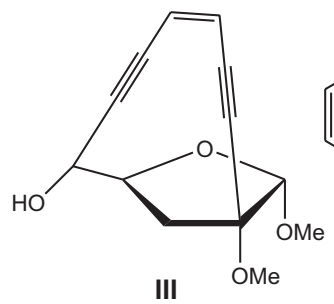

III

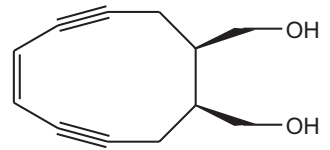

II

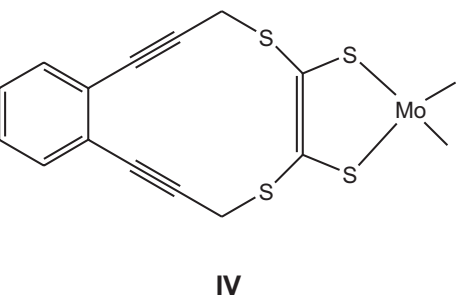

Fig. 6. Examples of some designed enediynes.

Delivery system. - To ensure delivery of the enediyne model system to the site of action, they have been attached to numerous molecules that are known to interact with the DNA. The hybrid molecule composed of simple cyclic arene enediyne and synthetic a minor-groove binder structure was found to cleave single-stranded DNA at $40{ }^{\circ} \mathrm{C}$ (32). Also, coupling of simple cyclic enediyne with an analogue of netropsin, minor-groove DNA binder, gave a hybrid molecule with 2000-fold increased DNA cleaving efficiency compared to an enediyne alone (33).

Specific elimination of cancer cells by the treatment with chemotherapeutics is usually hindered by their low selectivity. Recent approaches tend to overcome this drawback by using antibody-targeted strategy in cancer therapy. This strategy is based on conjugates of cytotoxic agents and antibodies specific for a tumor-associated antigen. Many experiments have showed increased DNA cleaving activity and cancer cell growth inhibition by such immunoconjugates.

Triggering device. - Bergman cycloaromatization is of great utility if one has control over it. Thus, extensive work has been done in searching for adequate triggering mechanisms. Simple dynemicin model compound V (Fig. 7) gave a product of Bergman cyclization upon epoxide opening in the presence of an acid catalyst. Dynemicin model VI (Fig. 7) can be activated photochemically under neutral conditions, while the presence of a base triggers cycloaromatization of VII (Fig. 7) (25).

In recent years, considerable effort has been invested into understanding the photochemical aspect of Bergman cycloaromatization and thereby into the development of enediyne compounds equipped with suitable photo-labile groups. Upon irradiation with visible or UV light without metal ions or reducing agents, these compounds are expected to form reactive diradicals capable of DNA cleavage. 
<smiles>C#CC#C[C@@H]1O[C@@]12c1ccccc1N(C(=O)OCC)C#C[C@@H]2C#C</smiles>

V

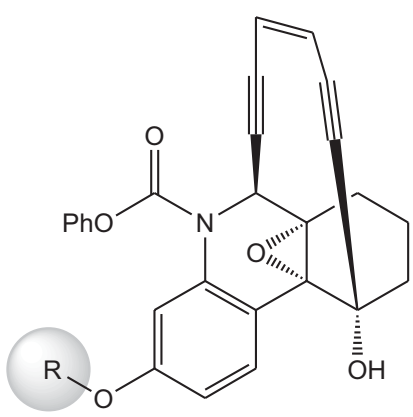

VI $\left(\mathrm{R}=-\mathrm{CH}_{2}-\mathrm{C}_{6} \mathrm{H}_{4}-\mathrm{O}-\mathrm{NO}_{2}\right)$

VII $(\mathrm{R}=-\mathrm{CO} t-\mathrm{Bu})$

Fig. 7. Dynemicin model compounds with different triggers.

\section{NATURALLY OCCURING ENEDIYNES}

\section{Neocarzinostatin}

The natural antibiotic neocarzinostatin (NCS) was first reported in 1965 (34), when it was isolated from Streptomyces carzinostaticus Var. F-41. It is a complex consisting of a 1:1 non-covalently associated mixture of protein (NCS apoprotein) and a chromoforic (NCS chromophore) component (Fig. 8). It was soon recognised that chromophoric moiety yields biological activity and that NCS apoprotein stabilizes and transports the drug (19).
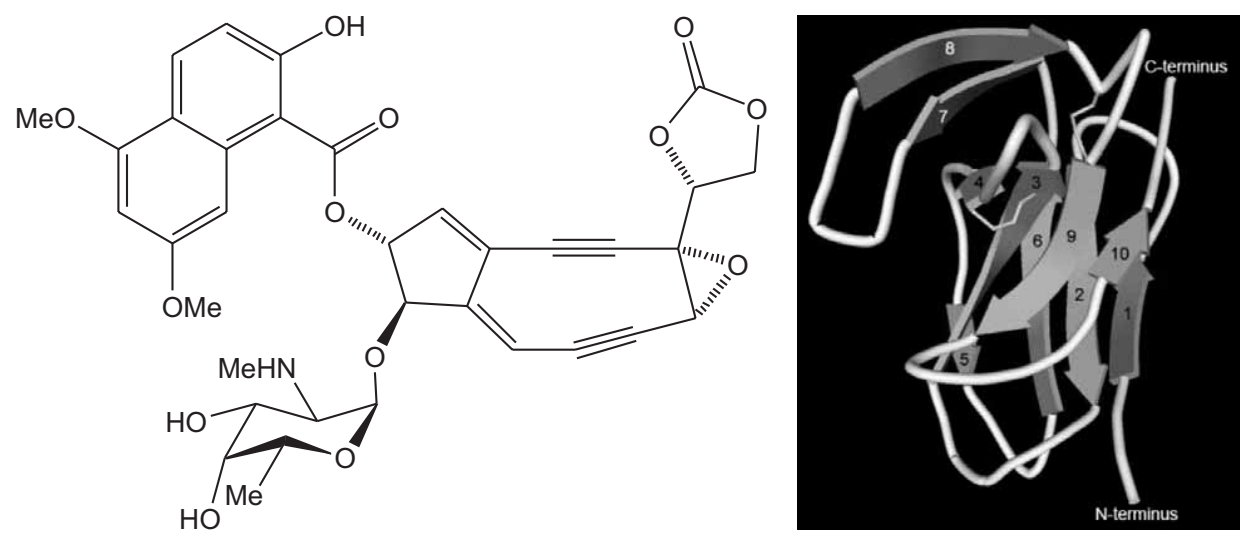

Fig. 8. Neocarzinostatin chromophore (left) and apoprotein (right) (24). 
NCS apoprotein consists of a 113 amino acid polypeptide chain. It binds firmly and specifically to the chromophore and delivers chromophore to the site of action, the DNA molecule, by controlled release. It was also reported (35) that NCS apoprotein possesses cytotoxic activity; it acts upon proteolytic activity.

Potent antitumor and antibacterial activity of NCS is manifested through the DNA cleavage. NCS chromophore intercalates into the DNA with its naphtoate side chain, which positions the rest of the molecule within the minor groove. Biologically active free NCS chromophore moiety cuts single-strands of the DNA, which is followed by an oxygen-dependent reaction. Cleaving properties of the NCS chromophore are greatly enhanced by thiols and UV radiation (17).

The mechanism by which the NCS chromophore destroys the DNA (Fig. 9) was first proposed in 1987 (18). The cascade of reactions that leads to the destruction of the DNA begins with the stereospecific nucleophilic attack at $\mathrm{C}(12)$, e.g., thiols. This triggering event is followed by the rearrangement of the ring skeleton and epoxide opening; it leads to the formation of cumulene structure 2 . This incurred highly strained and reactive intermediate undergoes instant cycloaromatization and forms the diradical 3 . The diradical thereupon attacks DNA with abstraction of DNA's two hydrogen atoms, which results in 4 .
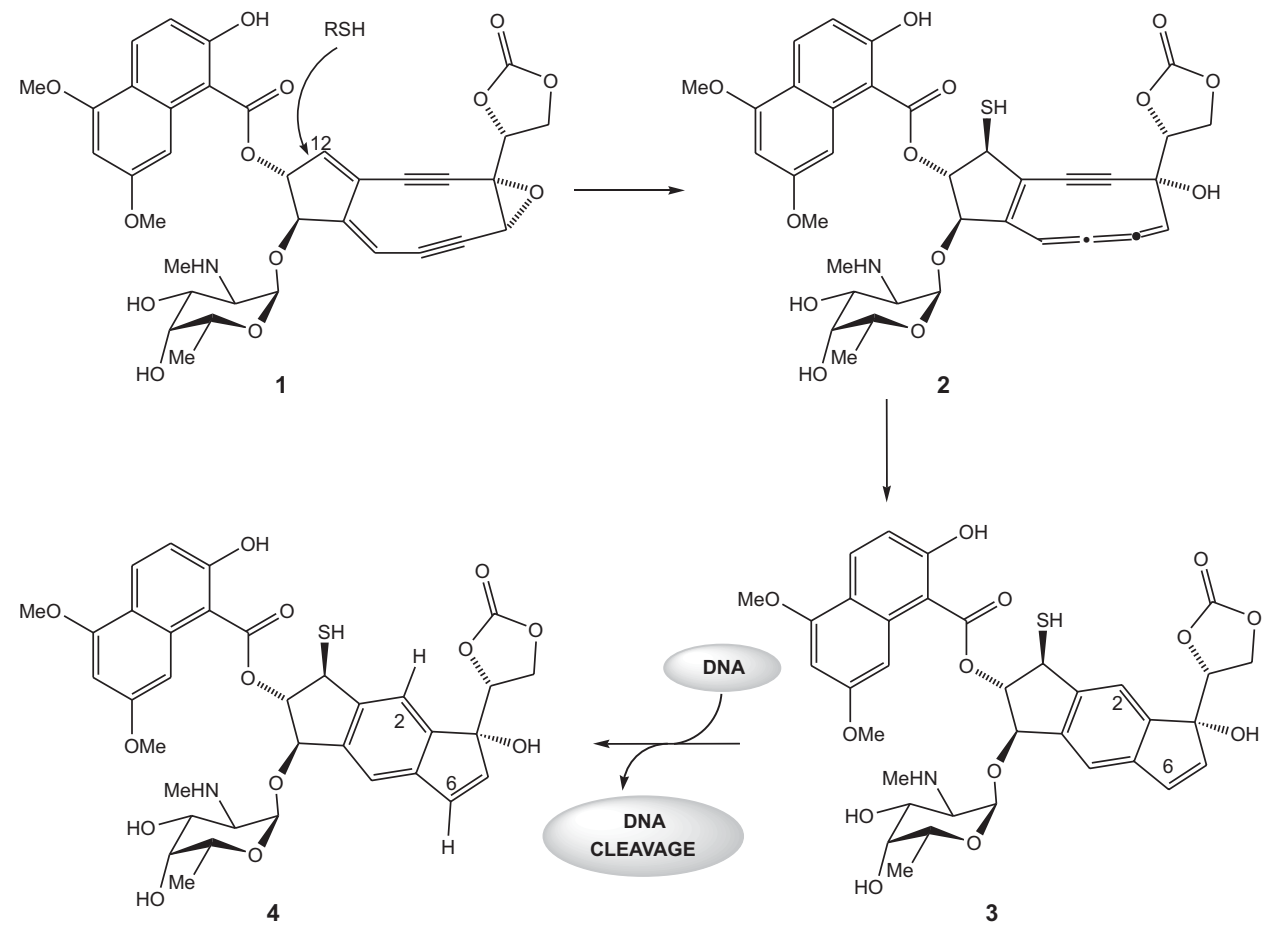

Fig. 9. Triggering pathway for the NCS chromophore. 
The role of the NCS apoprotein is clearly seen in information provided by the three-dimensional solution structure of intact NCS. The aminomethyl group of the sugar pendant is forced into close proximity of $\mathrm{C}(12)$. The reason is a salt bridge with asparagine 33 in a polypeptide chain. Nucleophilic attack may be aided by basic nitrogen of asparagine and sterical interferences at $\mathrm{C}(12)$ of the amino acids serine 98 , asparagine 33 and phenylalanine 52 in a polypeptide chain. This results in positioning the epoxide in a hydrophobic pocket away from acid catalysts.

DNA damage induced by the formation of diradical 3 occurs at two abstraction points in the deoxyribose. The first abstraction point, which causes $80 \%$ of DNA cleavages, is $C\left(5^{\prime}\right)$ atom of adenine and thymine residues. Less than $20 \%$ of strand breaks result after the abstraction of hydrogen atom from $C\left(1^{\prime}\right)$ and $C\left(4^{\prime}\right)$. When single-strand DNA cuts appear, usually the $\mathrm{C}\left(5^{\prime}\right)$ hydrogen is abstracted by $\mathrm{C}(6)$ in the diradical 3 , whereas double strand DNA lesions involve additional $\mathrm{C}\left(1^{\prime}\right)$ or $\mathrm{C}\left(4^{\prime}\right)$ abstraction by the $\mathrm{C}(2)$ radical.

Recently, it was observed that thiol independent DNA cleavage is possible. It happens when a DNA molecule contains regions where double-stranded structures are generated intramolecularly and, thus, appear as single-strands. If that is the case, DNA would be a participant in its own destruction (18).

NCS is actually a prodrug that requires sulfhydryl activation for the activity (Fig. 9), which results in lower selectivity and cytotoxic activity. Initial clinical trials were hindered by anaphylactic responses due to its non-covalently bound protein component. To prevent this alergic reaction, NCS protein has been rendered immunologically inert by coupling to a maleic acid-based polymer (SMANCS) and is clinically used primarily in the treatment of hepatocellular carcinoma (36).

\section{Calicheamicins}

The calicheamicins (Fig. 10) are a family of enediyne antibiotics isolated from Micromonospora echinospora spp. calichensis. They were identified in 1986 through a research program that identified microbial fermentation products active in the biochemical induction assay (20).

Calicheamicin $\gamma_{1}{ }^{\mathrm{I}}$ is the most distinguished member of this class of compounds. Calicheamicins with iodine, which are obtained by treating a fermentation broth with sodium iodide, have shown better yields than the ones containing bromine. The calicheamicins are extremely active against Gram-positive bacteria and highly active against Gram-negative bacteria. Most importantly, they exhibit extraordinary activity against murine tumors, such as leukemia and solid neoplasms (37). The calicheamicins are profoundly potent sequence specific, double strand DNA-cleaving agents.

The chemical structure of calicheamicin $\gamma_{1}{ }^{\mathrm{I}}$ (Fig. 10) can be divided into two distinct structural regions, containing three essential components. The larger of the two structural regions consists of an oligosaccharide sugar part (four monosaccharide units) and one hexasubstituted benzene ring. These two are joined together through a highly unusual series of glycosidic, thioester and hydroxylamine linkages. The second structural region, the aglycon (termed calicheamicinone), contains a highly functionalized bicyclic core accommodating a strained enediyne unit within a bridging 10-membered ring. It also contains a trisulfide moiety, which acts as a triggering device. 


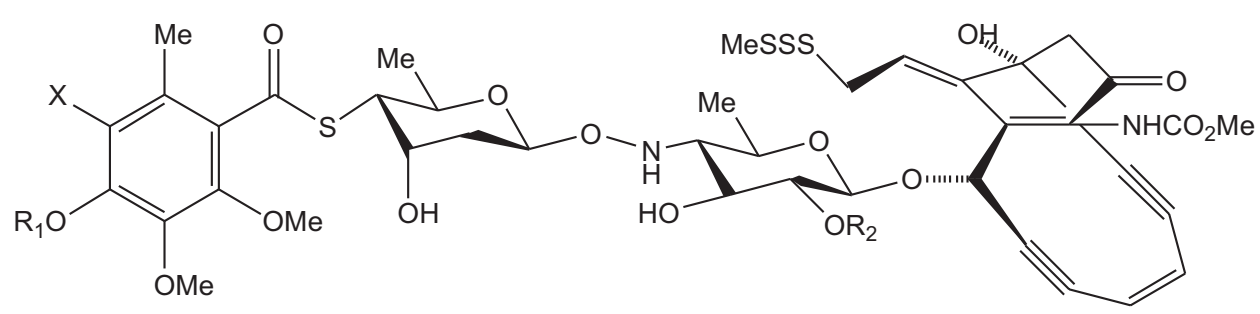<smiles>[R3]NC1CO[C@@H](C)C[C@@H]1OC</smiles>

\begin{tabular}{lcccc}
\hline Calicheamicin & $\mathrm{X}$ & $\mathrm{R}_{1}$ & $\mathrm{R}_{2}$ & $\mathrm{R}_{3}$ \\
\hline Calicheamicin $\beta_{1}{ }^{\mathrm{Br}}$ & $\mathrm{Br}$ & $\mathrm{Rha}$ & $\mathrm{Ami}$ & $\mathrm{CHMe}$ \\
Calicheamicin $\gamma_{1}^{\mathrm{Br}}$ & $\mathrm{Br}$ & $\mathrm{Rha}$ & $\mathrm{Ami}$ & $\mathrm{Et}$ \\
Calicheamicin $\alpha_{1}{ }^{\mathrm{I}}$ & $\mathrm{I}$ & $\mathrm{H}$ & $\mathrm{Ami}$ & $\mathrm{Et}$ \\
Calicheamicin $\alpha_{3}{ }^{\mathrm{I}}$ & $\mathrm{I}$ & $\mathrm{Rha}$ & $\mathrm{H}$ & $\mathrm{H}$ \\
Calicheamicin $\beta_{1}{ }^{\mathrm{I}}$ & $\mathrm{I}$ & $\mathrm{Rha}$ & $\mathrm{Ami}$ & $\mathrm{CHMe}$ \\
Calicheamicin $\gamma_{1}{ }^{\mathrm{I}}$ & $\mathrm{I}$ & Rha & $\mathrm{Ami}$ & $\mathrm{Et}$ \\
Calicheamicin $\delta_{1}{ }^{\mathrm{I}}$ & $\mathrm{I}$ & Rha & $\mathrm{Ami}$ & $\mathrm{Me}$ \\
\hline
\end{tabular}

Fig. 10. Calicheamicin family.

The aryltetrasaccharide delivers the drug to its target, binding tightly into the minor groove of double-helical DNA, displaying high specificity for sequences 5'-TCCT-3' and 5'-TTTT-3' through significant hydrophobic interactions $(38,39)$. This binding is facilitated by transformation of the oligosaccharide component into an inflexible, extended conformation, which provides distinctive torsion angles in the central region of the molecule, necessary to complement the minor groove of the DNA. The DNA appears to distort itself upon binding, in order to accommodate the drug (induced fit). In addition to the sequence recognition by an aglycone and aryl oligosaccharide part, large and polarizable iodine in the hexasubstituted benzene ring takes part in the recognition process as well.

As mentioned above, aglycone is a rigid bicyclic core, a 10-membered ring containing enediyne moiety awaiting activation to undergo cycloaromatization. It contains an 
allylic trisulfide as well, which serves as a trigger. When the drug comes into the vicinity of the DNA, a nucleophile (e.g., glutathione) attacks the central sulfur atom in the allylic trisulfide. This leads to the formation of a thiol, which adds intramolecularly to the neighbouring $\alpha, \beta$-unsaturated ketone incorporated within the bicyclic core (Fig. 4). The change in structural geometry of an aglycone leads to a great deal of strain of the 10-membered enediyne ring. At this point, the Bergman cycloaromatization takes place, forming a highly reactive 1,4-benzenoid diradical. The calicheamicin diradical abstracts hydrogen atoms from both DNA strands: $C\left(5^{\prime}\right)$ position of the cytidine and $C\left(4^{\prime}\right)$ of the three base pairs removed on the $3^{\prime}$ side of the complementary strand. Hence, the cleavage of both DNA strands occurs.

Natural calicheamicins are a thousand times more potent than conventional cytotoxic chemotherapeutics. The calicheamicin $\gamma_{1}{ }^{\mathrm{I}}$ has been coupled with antibodies to tumor-specific antigens and has been proposed as a targeted therapy for breast cancer (40). The first clinically validated cytotoxic immunoconjugate in which a humanized anti-CD33 antibody is linked to a calicheamicin derivate is called gentuzumab ozogamicin. It is indicated for the treatment of elderly patients with relapsed acute myeloid leukaemia. A similar conjugate, inotuzumab ozogamicin, is presently in Phase I clinical trials in patients with non-Hodgkin's lymphoma. Today, a number of tumor-targeted immunoconjugates of calicheamicin are being researched preclinically.

\section{Esperamicins}

Esperamicins are a subgroup of naturally occurring enediyne antibiotics. They bespeak high efficiency as broad-spectrum antibiotics and antitumor agents. Esperamicins were isolated from the fermentation broth of Actinomadura verrucosospora (21). The name of this enediyne group was derived from the place where the producing organism was collected, Pto Esperanza in Argentina.

The molecular structure of the esperamicin family (Fig. 11) was cleared in 1987. The resemblance of the structure of esperamicins to the structure of calicheamicins is quite astonishing; they differ from calicheamicins only in an additional hydroxyl group in the bicyclic core and rather unusual structural motifs in sugar appendages. Other than similarity in structure, they also have similarities in biological activity and mode of action.

Like calicheamicins, esperamicins exert their biological activity by damaging the DNA. The mechanism of DNA cleavage by esperamicin $A_{1}$, the most eminent representative of the esperamicin family, is identical to the DNA cleavage of calicheamicin $\gamma_{1} \mathrm{I}$ (Fig. 4) (41). However, esperamicin $A_{1}$ exhibits less sequence selectivity than calicheami$\operatorname{cin} \gamma^{1}$. The activity of esperamicin $\mathrm{A}_{1}$ towards DNA is significantly enhanced by thiols, such as dithiothretiol, and results in single and double strand cuts. The sugar appendages assist the drug binding into the minor groove of the DNA, just like in the case of calichemicin $\gamma_{1}{ }^{\mathrm{I}}$, while pro-radical carbon atoms of the enediyne moiety in the bicyclic core are positioned towards the $C\left(4^{\prime}\right)$ and $C\left(5^{\prime}\right)$ hydrogen atoms, where abstraction occurs (Fig. 12).

The esperamicins are among the most powerful antitumor agents known. They exhibit a forceful activity against a number of murine tumor models. Despite the number of side effects, esperamicin $A_{1}$ has successfully passed Phase I and is now in Phase II clinical trials. 


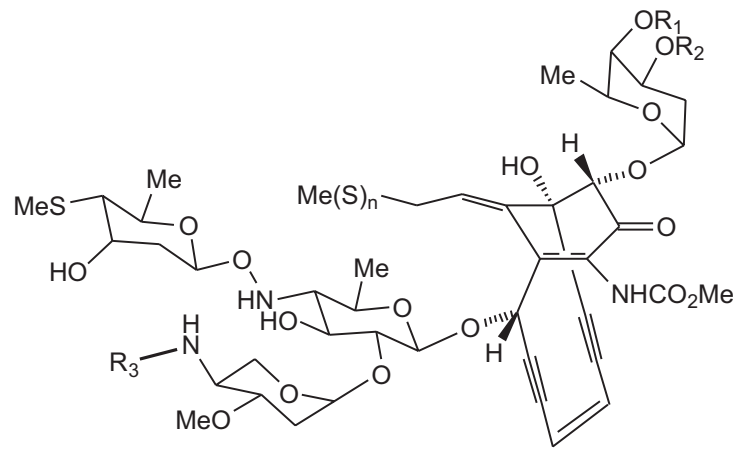<smiles>C=C(OC)C(=O)Nc1cc(OC)c(OC)cc1C(=O)OC</smiles>

\begin{tabular}{llllc}
\hline Esperamicin & $\mathrm{n}$ & $\mathrm{R}_{1}$ & $\mathrm{R}_{2}$ & $\mathrm{R}_{3}$ \\
\hline Esperamicin $\mathrm{A}_{1}$ & 3 & $\mathrm{H}$ & $\mathrm{Ar}$ & $\mathrm{CHMe}_{2}$ \\
Esperamicin $\mathrm{A}_{1 \mathrm{~b}}$ & 3 & $\mathrm{H}$ & $\mathrm{Ar}$ & $\mathrm{Et}$ \\
Esperamicin $\mathrm{A}_{1 \mathrm{c}}$ & 3 & $\mathrm{H}$ & $\mathrm{Ar}$ & $\mathrm{Me}$ \\
Esperamicin $\mathrm{P}$ & 4 & $\mathrm{H}$ & $\mathrm{Ar}$ & $\mathrm{CHMe}_{2}$ \\
Esperamicin $\mathrm{A}_{2}$ & 3 & $\mathrm{Ar}$ & $\mathrm{H}$ & $\mathrm{CHMe}_{2}$ \\
Esperamicin $\mathrm{A}_{2 \mathrm{~b}}$ & 3 & $\mathrm{Ar}$ & $\mathrm{H}$ & $\mathrm{Et}$ \\
Esperamicin $\mathrm{A}_{2 \mathrm{c}}$ & 3 & $\mathrm{Ar}$ & $\mathrm{H}$ & $\mathrm{Me}$ \\
\hline
\end{tabular}

Fig. 11. The esperamicin family.

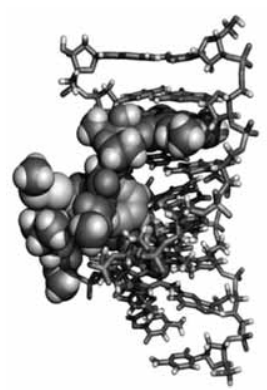

Fig. 12. Esperamicin A1 bound to the minor groove of the DNA (42).

\section{Dynemicins}

The member of the dynemicin family of enediyne antibiotics that was first discovered is dynemicin A (Fig. 13). This is a violet-colored solid isolated from the fermentation broth of Micromonospora chersina (22). Its molecular structure was fully determined in 1989 with the exception of absolute configuration, which was confirmed later on by total synthesis. Dynemicin A exhibits high efficiency against a variety of cancer cell lines 


\begin{tabular}{lc}
\hline Dynemicin & $\mathrm{R}$ \\
\hline Dynemicin A & $\mathrm{OH}$ \\
Deoxydynemicin A & $\mathrm{H}$ \\
\hline
\end{tabular}

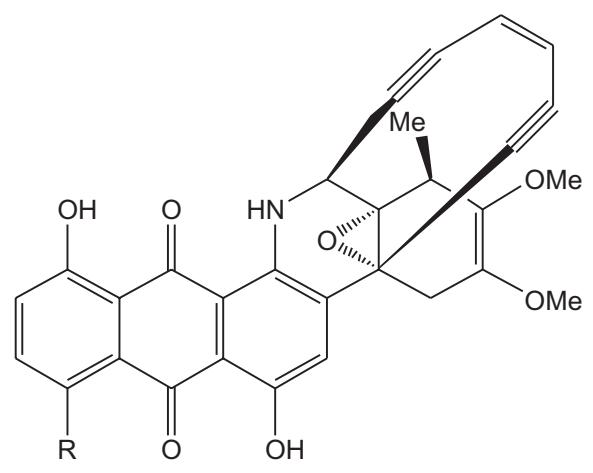

Fig. 13. The dynemicin family.

and prolongs significantly the life span of mice inoculated with leukemia and melanoma cells (43). Moreover, dynemicin A and its derivates exhibit antibacterial activity in vivo with low toxicity. Recently, another member of the dynemicin family emerged as a bioactive compound. Deoxydynemicin A (Fig. 13) was isolated from Micromonospora globosa and has a similar biological profile as dynemicin A (18).

The molecular structure of dynemicins includes a 10-membered ring with enediyne moiety embedded within an anthraquinone chromophore, typical of anthracycline antibiotics, e.g., doxorubicin. Intercalation of the anthraquinone portion of dynemicin A into the minor groove of the DNA is the first step in a cascade reaction that leads to DNA cleavage. This intercalation is associated with local distortion of the DNA in order to accommodate the drug; the dynemicin molecule recognizes conformationally flexible regions of the DNA and acts as a »molecular wedge «. Anthraquinone then undergoes bioreduction to give the anthraquinol. The electron-rich anthraquinol is now able to open the epoxide moiety, which is accompanied with rapid cycloaromatization of the enediyne moiety. 1,4-Benzenoid diradical strips hydrogen atoms from the DNA, resulting in single and double-helix cleavages $(18,44)$. The potency of cycloaromatization is enhanced by thiols and light irradiation and the preferred sites of dynemicin A attacks are $3^{\prime}$ sides of purine bases, such as 5'-AG, 5'-GC, 5'-GT and 5-AT.

Dynemicin A is currently in Phase III clinical trials. Prodrugs of dynemicin A are much more interesting than dynemicin A alone, because of the possibility to activate them by aldolase antibody 38C2 specifically inside tumor cells (43).

\section{CONCLUSIONS}

Enediyne anticancer antibiotics and their derivatives are considered to be lead candidates in combating one of the major diseases today. Calicheamicin seems to be heading most directly to clinical studies, compared to the other enediynes. Efforts to attach calicheamicin to various drug antibody conjugates that seem suitable for clinical trials make calicheamicin an enediyne of interest. At the same time, exploring the genomes of 
two soul microbes, genes that govern the production of enediynes are disclosed. This finding will, by all means, allow improvement in the production but also in the development of new enediyne-related compounds with DNA cleaving ability.

Acknowledgement. - This work was supported by the Croatian Ministry of Science, Education and Sport, Grant No. 098-0982933-2936.

Abbreviations and symbols. - A - adenine, BLM - bleomycin, C - cytosine, DNC - daunorubicin, DOX - doxorubicin, G - guanine, NCS - neocarzinostatin, PEP - pepleomycin, T - thymine, $\mathrm{U}$ - uracil.

\section{REFERENCES}

1. X. L. Yang and A. H.-J. Wang, Structural studies of atom-specific anticancer drugs acting on DNA, Pharmacol. Therapeut. 83 (1999) 181-215; DOI: 10.1016/S0163-7258(99)00020-0.

2. N. A. Illan-Cabeza, R. A. Vilaplana, Y. Alvarez, K. Akdi, S. Kamah, F. Hueso-Urena, M. Quiros, F. Gonzalez-Vilchez and M. N. Moreno-Carretero, Synthesis, structure and biological activity of a new and efficient $\mathrm{Cd}(\mathrm{II})$-uracil derivative complex system for cleavage of DNA, J. Biol. Inorg. Chem. 10 (2005) 924-934; DOI: 10.1007/s00775-005-0045-x.

3. I. Haq and J. Ladbury, Drug-DNA recognition: Energetics and implications for design, J. Mol. Recognit. 13 (2000) 188-197; DOI: 10.1002/1099-1352(200007/08)13:4<188::AID-JMR503>3.0.CO;2-1.

4. R. Barthwal, U. Sharma, N. Snivastava, M. Jain, P. Awasthi, M. Kaur, S. K. Barthwal and G. Govil, Structure of daunomycin complexed to d-TGATCA by two-dimensional nuclear magnetic resonance spectroscopy, Eur. J. Med. Chem. 41 (2006) 27-39; DOI: 10-1016/j.ejmech.2005.09.005.

5. J. Chen and J. Stubbe, Bleomycins: new methods will allow reinvestigation of old issues, Curr. Opin. Chem. Biol. 8 (2004) 175-181; DOI: 10.1016/j.cbpa.2004.02.008.

6. S. E. Wolkenberg and D. L. Boger, Mechanisms of in situ activation for DNA-targeting antitumor agents, Chem. Rev. 102 (2002) 2477-2495; DOI: 10.1021/cr010046q.

7. Y. L. Janin, Peptides with anticancer use or potential, Amino Acids 25 (2003) 1-40; DOI 10.1007/ s00726-002-0349-xPeptides.

8. I. Jerić, L. Šimičić, M. Stipetić and Š. Horvat, Synthesis and reactivity of the monosaccharide esters of amino acids as models of teichoic acid fragment, Glycoconjugate J. 17 (2000) 273-282; DOI: $10.1023 / \mathrm{A}: 1007157018792$.

9. I. Jerić and Š. Horvat, Novel ester-linked carbohydrate-peptide adducts: Effect of peptide substituent on the pathways of intramolecular reactions, Eur. J. Org. Chem. (2001) 1533-1539; DOI: 10.1002/1099-0690(200104)2001:8<1533::AID-EJOC1533>3.0.CO;2-Y.

10. I. Jerić, P. Novak, M. Vinković and Š. Horvat, Conformational analysis of sugar-peptide adducts in solution state by NMR spectroscopy and molecular modelling, J. Chem. Soc., Perkin Trans 2 2001, 1944-1950; DOI: 10.1039/b104239b.

11. Š. Horvat, I. Jerić, L. Varga-Defterdarović, M. Roščić and J. Horvat, Ester-linked glycopeptides as tools for the study of biological phenomena, Croat. Chem. Acta 74 (2001) 787-799.

12. I. Jerić, C. Versluis, Š. Horvat and A. J. R. Heck, Tracing glycoprotein structures: electrospray ionization tandem mass spectrometric analysis of sugar-peptide adducts, J. Mass Spectrom. 37 (2002) 803-811; DOI: 10.1002/jms.337.

13. I. Jerić and Š. Horvat, Glycoconjugates as models in biomedical studies, Kem. Ind. 53 (2004) 63-70.

14. I. Jerić, Peptide mimetics: why and how? Kem. Ind. 53 (2004) 495-504.

15. I. Jerić and H. M. Chen, Synthesis of an Enedyine-bridged Peptide for Cell Lysis, in Peptides 2004. Bridges Between Disciplines (Eds. M. Flegel, M. Fridkin, C. Gilon and J. Slaninova), Kenes International, Geneva 2005, pp. 218-219. 
16. I. Jerić, M. Momčilović, I. Bratoš and Š. Horvat, Synthesis of trehalose-centered dipeptide esters, Croat. Chem. Acta 79 (2006) 261-272.

17. K. C. Nicolaou, A. L. Smith, and E. W. Yue, Chemistry and biology of natural and designed enediynes, Proc. Nat. Acad. Sci. USA 90 (1993) 5881-5888.

18. A. L. Smith and K. C. Nicolaou, The enediyne antibiotics, J. Med. Chem. 39 (1996) 2103-2117; DOI: $10.1021 /$ jm9600398.

19. K. Edo, M. Mizugaki, Y. Koide, H. Seto, K. Furihata, N. Otake and N. Ishida, The structure of neocarzinostatin chromophore possessing a novel bicyclo-[7,3,0]dodecadiyne system, Tetrahedron Lett. 26 (1985) 331-334; DOI: 10.1016/S0040-4039(1)80810-8.

20. M. D. Lee, T. S. Dunne, C. C. Chang, G. A. Ellestad, M. M. Siegel, G. O. Morton, W. J. McGahren and D. B Borders, Calichemicins, a novel family of antitumor antibiotics. 2. Chemistry and structure of calichemicin gamma1I, J. Am. Chem. Soc. 109 (1987) 3466-3468; DOI: 10.1021/ja00245a051.

21. J. Golik, J. Clardy, G. Dubay, G. Groenwold, H. Kawaguchi, M. Konishi, B. Krishnan, H. Ohkuma, K. Saitoh and T. W. Doyle, Esperamicins, a novel class of potent antitumor antibiotics. 2. Structure of esperamicin X, J. Am. Chem. Soc. 109 (1987) 3461-3462; DOI: 10.1021/ja00245a048.

22. M. Konishi, H. Ohkuma, T. Tsuno, T. Oki, G. D. VanDuyne and J. Clardy, Crystal and molecular structure of dynemicin A: A novel 1,5-diyn-3-ene antitumor antibiotic, J. Am. Chem. Soc. 112 (1990) 3715-3716; DOI: 10.1021/ja00165a097.

23. R. R. Jones and R. G. Bergman, $p$-Benzyne: Generation as an intermediate in a thermal isomerization reaction and trapping evidence for the 1,4-benzenediyl structure. J. Am. Chem. Soc. 94 (1972) 660-661; DOI: 10.1021/ja00757a071.

24. P. C. Dedon, A. A. Salzberg and J. Xu, Exclusive production of bistranded DNA damage by calicheamicin, Biochemistry 32 (1993) 3617-3622; DOI: 10.1021/bi00065a013.

25. J. W. Grissom, G. U. Gunawardena, D. Klingberg and D. Huang, The chemistry of enediynes, enyne, allens and related compounds, Tetrahedron 52 (1996) 6453-6518; DOI: 10.1016/0040-4020 (96)00016-6.

26. E. W. Schmitt, J. C. Huffman and J. M. Zaleski, Thermal reactivities of isostructural $\mathrm{d}^{10}$ metalloenediynes: metal-dependent Bergman cyclization, Chem. Commun. 2001, 167-168; DOI: 10.1039/ b008337m.

27. I. Saito and K. Nakatani, Design of DNA-cleaving agents, Bull. Chem. Soc. Jpn. 69 (1996) 3007-3019; DOI: $10.1246 /$ bcsj.69.3007.

28. H. H. Wenk, M. Winkler and W. Sander, One century of aryne chemistry, Angew. Chem. Int. Ed. 42 (2003) 502-528; DOI: 10.1002/anie.200390151.

29. K. C. Nicolaou, G. Zuccarello, C. Riemer, V. A. Estevez and W.-M. Dai, Design, synthesis and study of simple monocyclic conjugated - enediynes. The 10-membered ring enediyne moiety of the enediyne anticancer antibiotics, J. Am. Chem. Soc. 114 (1992) 7360-7371; DOI: 10.1021/ja00045a005.

30. M. E. Maier and T. Brandstetter, Synthesis of an oxabicyclo[7.2.1.] enediyne from a furanoside derivative, Tetrahedron Lett. 33 (1992) 7511-7514; DOI: 10.1016/s0040-4039(00)60-810-9.

31. S. Bhattacharyya, M. Pink, M.-H. Baik and J. M. Zaleski, A unique approach to metal-induced Bergman cyclization: long range enediyne activation by ligand-to-metal charge transfer, Angew. Chem. Int. Ed. 44 (2005) 592-595; DOI: 10.1002/anie.200461825.

32. D. L. Boger and J. Zhou, CDPI3-enediyne and CDPI3-EDTA conjugates: a new class of DNA cleaving agents, J. Org. Chem. 58 (1993) 3018-3024; DOI: 10.1021/jo0006a019.

33. N. Ishida, K. Miyazaki, K. Kumagai and M. Rikimaru, Neocarzinostatin, an antitumor antibiotic of high molecular weight, J. Antibiot. 18 (1965) 68-76.

34. M. F. Semmelhack, J. J. Gallagher, W.-D. Ding, G. Krishnamurthy, R. Babine and G. A. Ellestad, The effect on DNA cleavage potency of tethering a simple cyclic enediyne to a netropsin analog, J. Org. Chem. 59 (1994) 4357-4359; DOI: 10.1021/jo00095a002. 
35. N. Zein, A. M. Casazza, T. W. Doyle, J. E. Leet, D. R. Schroeder, W. Solomon and S. G. Nadler, Selective proteolitic activity of the antitumor agent kedarcidin, Proc. Nat. Acad. Sci. USA 90 (1993) 8009-8012; DOI: 10.1073/pnas.90.17.8009.

36. C. G. Sudhahar and D. H. Chin, Aponeocarzinostatin - A superior drug carrier exhibiting unusually high endurance against denaturants, Bioorg. Med. Chem. 14 (2006) 3543-3552; DOI: 10.1016/ j.bmc.2006.01.012.

37. N. F. Schor, V. E. Kagan, Ye Liang, Ch. Yan, Yu. Tyurina, V. Tyurin and K. D. Nylander, Exploiting oxidative stress and signaling in chemotherapy of resistant neoplasms, Biochemistry (Moscow) 69 (2004) 38-44; DOI: 10.1023/B:BIRY.0000016349.75384.e6.

38. N. Zein, M. Poncin, R. Nilakantan and G. A. Ellestad, Calicheamicin $\gamma_{1}{ }^{\mathrm{I}}$ and DNA: Molecular recognition process responsible for site-specificity; Science 244 (1989) 697-699.

39. S. Walker, J. Murnick and D. Kahne, Structural characterization of a calicheamicin-DNA complex by NMR, J. Am. Chem. Soc. 115 (1993) 7954-7961; DOI: 10.1021/ja00071a004.

40. N. K. Damle, Tumour-targeted chemotherapy with immunoconjugates of calicheamicin, Expert Opin. Biol. Ther. 4 (2004) 1445-1452; DOI: 10.1517/14712598.4.9.1445.

41. K. C. Nicolaou and W.-M. Dai, Chemistry and biology of the enediyne anticancer antibiotics, Angew. Chem. Int. Ed. 30 (1991) 1387-1416; DOI: 10.1002/anie.199113873.

42. S. Feldgus, Expanding the cancer fighting arsenal, www.hamilton.edu/enews/200202.html, accessed 16.01.2006.

43. S. C. Sinha, Lian-Sheng Li, G. P. Miller, S. Dutta, C. Rader and R. A. Lerner, Prodrugs of dynemicin analogs for selective chemotherapy mediated by an aldose catalytic Ab, Proc. Nat. Acad. Sci. USA 9 (2004) 3095-3099; DOI: 10.1073/pnas.0307319101.

44. Y. Suguira, T. Shiraki, M. Konishi and T. Oki, DNA Intercalation and cleavage of an antitumor antibiotic dynemicin that contains anthracycline and enediyne cores, Proc. Nat. Acad. Sci. USA 87 (1990) 3831-3835; DOI: 10.1073/pnas.87.10.3831.

\section{$S A \check{Z} E T A K$}

\section{Endiinski spojevi - novi antitumorski lijekovi}

MATIJA GREDIČAK i IVANKA JERIĆ

Znanstvenici raznih profila dugo su bili intrigirani prirodom, mehanizmom djelovanja i potencijalom prirodnih toksina s izuzetnom antibakterijskom i antitumorskom aktivnošću. Ti spojevi, nazvani endiini, danas su među najaktivnijim kemoterapeutskim agensima. Često uspoređivani s inteligentnim oružjem, zbog jedinstvene strukture i sofisticiranog mehanizma kojim uništavaju molekulu DNA, endiinski antibiotici danas predstavljaju vodeće spojeve u antitumorskoj terapiji. Predstavnici endiinske skupine spojeva su u kliničkoj primjeni, premda je njihova primjena ograničena složenom strukturom, što ih čini zahtjevnim ciljem za sintetske kemičare. Ovaj rad daje pregled prirodnih endiina, mehanizma njihova djelovanja i sintetskih analoga sa sposobnošću cijepanja molekule DNA.

Ključne riječi: endiini, antitumorsko djelovanje, Bergmanova ciklizacija, cijepanje DNA 